\title{
Pattern of Major Salivary Gland Malignancies in B.P. Koirala Memorial Cancer Hospital
}

\author{
Rajina Sahi, ${ }^{1}$ Dilip Karmacharya, ${ }^{2}$ Dej Kumar Gautam, ${ }^{2}$ Anil Bikram Karki, ${ }^{2}$ Amar Shrestha ${ }^{2}$ \\ ${ }^{1}$ Department of Pathology, College of Medical Sciences, Bharatpur-10, Chitwan, Nepal, ${ }^{2}$ B.P. Koirala Memorial \\ Cancer Hospital, Bharatpur-11, Chitwan, Nepal.
}

\begin{abstract}
Background: Salivary gland tumors represent a different variety of histological types. The definite diagnosis of type of salivary gland tumor is required for proper treatment planning. The aim of this study was to evaluate the pattern of salivary gland malignancy in B.P. Koirala Memorial Cancer Hospital, Bharatpur, Chitwan. Methods: This cross-sectional study was carried out in patients of malignant salivary gland tumor registered in B.P. Koirala Memorial Cancer hospital retrospectively from September 2009 to August 2012. Results: Parotid gland was the most common sites for malignant salivary gland tumor $(80 \%)$ followed by submandibular gland (20\%). Mucoepidermoid carcinoma is the most common malignant salivary gland tumor of parotid gland and Adenoid cystic carcinoma was the most common malignant tumor of submandibular gland. Male: Female ratio was 1.5:1 with age range from 12 years to 71 years. Common age group for malignant salivary gland tumor was from 50 to 60 years. Conclusions: Parotid was the most common site whereas Mucoepidermoid carcinoma was the most common malignant tumor of major salivary gland.
\end{abstract}

Keywords: adenoid cystic carcinoma; acinic cell carcinoma; mucoepidermoid carcinoma; parotid gland; submandibular gland; salivary gland tumors.

\section{INTRODUCTION}

Salivary gland tumors are usually present as painless enlarging masses. Salivary glands are divided into major (parotid, submandibular and sublingual glands) and minor glands. Embryologically, the salivary glands are tubuloacinar structures arising from invaginations of the somatoderm (ectodermal) and foregut (endodermal). Neoplasms of the salivary glands are rare and account for approximately $3 \%$ to $6 \%$ of all tumors of the head and neck region. ${ }^{1}$ Between 64 to $80 \%$ of all primary epithelial salivary gland tumors occur in the parotid gland, $7-11 \%$ occur in the submandibular glands, $1 \%$ in occur in sublingual glands and $9-23 \%$ occur in minor glands. ${ }^{2}$ According to the Global Cancer Statistic 2018, the incidence of malignant salivary gland tumor worldwide is $0.3 \%$ of total new cases $(52,799){ }^{3}$ Risk of salivary gland malignancy rises with increasing smoking and alcohol consumption, ionizing irradiation is also a well documented cause. ${ }^{2}$ Patients are frequently old age and the cure rates are very poor for most histological types. It is very important to distinguish between benign from malignant tumors for further treatment planning of the patient. Fine Needle Aspiration along with imaging techniques such as CT scan and MRI are used for diagnostic purpose, but in most cases surgical excision of the tumor is required for definitive diagnosis. ${ }^{4}$ Thus, definitive diagnosis of histopathological type of salivary gland tumor pay a major role for management of these tumors.

\section{METHODS}

This cross-sectional study was conducted from September 2009 to August 2012 in the department of Pathology of B.P Koirala Memorial Cancer Hospital. The records of the patients were obtained retrospectively from the medical record section of the hospital which is the secondary source of data collection. Age, sex, site of tumor and histopathological types of tumor were recorded and descriptive analysis was done to calculate frequency, percentage and their relations. Aim of the study is to provide the overview of disease pattern of major salivary gland tumor in B.P. Koirala Memorial Cancer Hospital. It also help in planning the strategies to treat the disease. Inclusion criteria: All the major salivary gland malignancy registered in this hospital were included in this study. Exclusion criteria: Minor salivary gland tumor and benign salivary gland tumor were excluded in this study. Ethical clearance was taken from B.P. Koirala Memorial Cancer Hospital. All the biopsy specimens were fixed in $10 \%$ buffered formalin, routine processing of the tissue was done and staining was done with Hematoxylin and Eosin stain. Immunohistochemistry was also done in the required cases. The histopathology diagnosis of all the cases were again reviewed and classification of tumor was

Correspondence: Dr. Rajina Sahi, Department of Pathology, College of Medical Sciences and Teaching Hospital, Bharatpur-10, Chitwan, Nepal. Email: rajisa17@hotmail.com. Phone: +977-9855059408. Article received: 2019-03-16. Article accepted: 2019-06-29. 
done according to the World Health Organization (WHO) histological type of Salivary gland tumors.

\section{RESULTS}

During these three years study period, total of 45 cases of malignant salivary gland tumors were present. There were 27 male and 18 female with a male to female ratio of $1.5: 1$. The common age group of malignant salivary gland tumors was 50 to 60 years. The youngest age was 12 years and the oldest age was 71 years (Table 1).

\begin{tabular}{|lcc|}
\hline $\begin{array}{l}\text { Table 1. Age distribution of malignant salivary gland } \\
\text { tumors. }\end{array}$ & \multicolumn{2}{l|}{} \\
\hline Age distribution & $\begin{array}{c}\text { Male } \\
\text { Agemale } \\
20\end{array}$ & $\begin{array}{c}\text { Femal } \\
0(3.70 \%)\end{array}$ \\
$21-30$ & $1(3.70 \%)$ & $1(5.55 \%)$ \\
$31-40$ & $3(11.11 \%)$ & $3(16.66 \%)$ \\
$41-50$ & $5(18.51 \%)$ & $2(11.11 \%)$ \\
$51-60$ & $10(37.03 \%)$ & $8(44.44 \%)$ \\
$61-70$ & $5(18.51 \%)$ & $3(16.66 \%)$ \\
70 & $2(7.40 \%)$ & $1(5.55 \%)$ \\
Total & $27(60 \%)$ & $18(40 \%)$ \\
\hline
\end{tabular}

In these series, malignant salivary gland tumor was predominantly located in parotid (36 cases) followed submandibular gland (9 cases). During our study period, there was no any case of malignant salivary gland tumor in sublingual gland. The most common site for salivary gland malignancy was parotid gland $(80 \%)$ and the second most common site is submandibular gland (20\%) (Table 2).

\begin{tabular}{|lll|}
\hline $\begin{array}{l}\text { Table 2. Sex distribution of malignant } \\
\text { tumors. }\end{array}$ & & \\
\hline Tumor Type & Male & Female \\
Mucoepidermoid Carcinoma & $16(59.25 \%)$ & $10(55.55 \%)$ \\
Adenoid Cystic Carcinoma & $8(29.62 \%)$ & $6(33.33 \%)$ \\
Acinic Cell carcinoma & $2(7.40 \%)$ & $1(5.55 \%)$ \\
Salivary Duct carcinoma & $0(0 \%)$ & $1(5.55 \%)$ \\
Non Hodgkin Lymphoma & $1(3.70 \%)$ & $0(0 \%)$ \\
Total & $27(60 \%)$ & $18(40 \%)$ \\
\hline
\end{tabular}

Mucoepidermoid carcinoma was the most common malignant tumor of parotid and accounted for $66 \%$ of all malignant tumor in parotid, followed by Adenoid cystic carcinoma (22\%), Acinic cell carcinoma (5\%), Salivary duct carcinoma (3\%) and Non Hodgkin Lymphoma (3\%). In submandibular gland, Adenoid cystic carcinoma was the most

\begin{tabular}{|lcc|}
\hline $\begin{array}{l}\text { Table 3. Histological distribution of } \\
\text { salivary gland tumor in Parotid gland (80\%) } \\
\text { Submand in }\end{array}$ \\
\hline Parotid gland & $\begin{array}{c}\text { Number of } \\
\text { patients }\end{array}$ & Percent \\
Mucoepidermoid Carcinoma & 24 & $66 \%$ \\
Adenoid Cystic Carcinoma & 8 & $22 \%$ \\
Acinic Cell Carcinoma & 2 & $5 \%$ \\
Salivary Duct carcinoma & 1 & $3 \%$ \\
Non Hodgkins Lymphoma & 1 & $3 \%$ \\
Submandibular gland & & \\
Adenoid Cystic Carcinoma & 6 & $66 \%$ \\
Mucoepidermoid Carcinoma & 2 & $22 \%$ \\
Acinic Cell Carcinoma & 1 & $11 \%$ \\
\hline
\end{tabular}

common malignant salivary gland tumor $(66 \%)$ followed by Mucoepidermoid carcinoma (22\%) and Acinic cell carcinoma (11\%) (Table 3).

\section{DISCUSSION}

Malignant salivary gland tumors have a relatively low incidence as compared to other head and neck malignancy. Malignant Salivary gland tumors account for more than $0.3 \%$ of all malignancies and approximately $7 \%$ of all head and neck cancers. ${ }^{5}$ According to an epidemiological study done in Sweden from 1960 to 1989 showed only 85 new cases of malignant salivary gland tumor per year. ${ }^{6}$ In our study total 45 cases of malignant salivary gland tumors were present during three years study period. In our study, the common age for malignant salivary gland tumor was 50 to 60 years and Male:Female ratio was 1.5:1. Similarly, in different study done by various authors Gonzalez et al., Aliyu et al., ${ }^{8}$ Bashir et al. ${ }^{9}$, Jaafari-Ashkavandi et al., ${ }^{10}$ there was a predominance of salivary gland malignancy in the male group and malignant salivary gland tumor usually occur in older age group. In parotid gland, the commonest malignancy is the mucoepidermoid carcinoma followed by the adenoid cystic carcinoma. In both cases high histological grade or adverse pattern affects prognosis adversely. Histological differential is crucial in predicting the biological behavior of salivary neoplasms. Low-grade malignant tumors usually have an excellent prognosis whereas high grade tumors usually have an increased risk of regional and distant metastasis, and are associated with poor prognosis. ${ }^{11}$ Similar to our study, in other study done by Siro, Mucoepidermoid carcinoma is the most common malignant salivary gland cancer which consist of one-third of cases. ${ }^{2}$ Shishegar et al. had done comparison of distribution of salivary gland tumors in Iran and other countries where they found parotid was the most common site for malignant salivary gland tumor and the Mucoepidermoid carcinoma was the most common malignant tumor with a prevalence ranging from $4-12 \% .{ }^{13}$ In our study in parotid gland, Mucoepidermoid carcinoma $(66 \%)$ was the most common malignant salivary gland tumor followed by Adenoid cystic carcinoma (22\%), Acinic cell carcinoma (5\%), Salivary duct carcinoma (3\%) and Non-Hodgkins Lymphoma (3\%). In study done by Jones AS et al., in the Submandibular gland, Adenoid cystic carcinoma are common $(43 \%)$ whereas Mucoepidermoid carcinoma and Adenocarcinoma accounting for 17 and 11 percentage respectively. ${ }^{14}$ In the various studies done by Victor Shing Howe To et al., ${ }^{15}$ Vargas et al., ${ }^{16}$ Rajdeo et al. ${ }^{17}$ and Elumelu et al. ${ }^{18}$ that Mucoepidemoid was the most common malignant salivary gland tumor of parotid gland which is similar to our study. In our study Adenoid cystic carcinoma (66\%) is the most 
common malignant salivary gland tumor of submandibular gland, followed by Mucoepidermoid carcinoma (22\%) and Acinic cell carcinoma (11\%). In the ten years study of salivary gland tumor done by Bashir $\mathrm{S}$ et al, they reported Adenoid cystic carcinoma was the most common malignancy in submandibular gland $(12.90 \%))^{9} \quad$ Grading of Adenoid cystic carcinoma was done as cribriform or tubular (Grade I), less than $30 \%$ solid (Grade II) and greater than $30 \%$ solid (Grade III). ${ }^{19}$ The cribriform variant demonstrated worse prognosis in terms of local recurrence rate (up to $47 \%$ ). ${ }^{4}$ Histologically, salivary gland tumors represent the most heterogeneous group of tumors in the body. ${ }^{20}$ The World Health Organization (WHO) described 24 different histological subtypes in its 2005 classification of salivary gland tumors and also highlight that there is some geographic variation in the frequency of tumor types. ${ }^{21}$ The limitation of this study is that only major malignant salivary gland tumors are included in this study whereas minor malignant salivary gland tumors are not included in this study so pattern of minor malignant salivary gland is not present in this study.

\section{CONCLUSIONS}

The most common site for malignant salivary gland tumor was Parotid gland where as second most common site was submandibular gland. Mucoepidermoid carcinoma is the most common malignant salivary gland tumor of parotid gland and Adenoid cystic carcinoma was the most common malignant tumor of submandibular gland. An accurate histopathology diagnosis of malignant salivary gland tumors is essential for further treatment of the patient.

\section{REFERENCES}

1. OPCS. Cancer Statistic Registration Series. London: HMSO; 1985.

2. Jones AS. Malignant tumors of the salivary glands. In: Gleeson M, editor. Scott-Brown's Otorhinolaryngology, Head and Neck Surgery. 2. 7 ed. Great Britain: Edward Arnold Ltd; 2008. p.2493-2516.

3. Bray F, Ferlay J, Soerjomataram I, Siegel RL, Torre LA, Jemel A. Global cancer statistic 2018: GLOBOCAN estimates of incidence and mortality worldwide for 36 cancers in 185 countries. CA: a cancer journal for clinicians. 2018.

4. Arrangoiz R, Papavasiliuo P, Sarcu D, Galloway TJ, Ridge JA, Lango M. Current Thinking on Malignant Salivary Gland Neoplasms. Journal of Cancer Treatment and Research 2013;1(1):8-24.

5. Eskander $\mathrm{A}$, Irish $\mathrm{J}$, Freeman $\mathrm{J}$, Gullane $\mathrm{P}$, Gilbert R, Groome PA, et al. Overview of major salivary gland cancer surgery in Ontario (20032010). Journal of otolaryngology- head \& neck surgery $=$ Le Journal d'oto-rhino-laryngologie et de chirugie cervico-faciale. 2014;43:50.

6. Ostaman J, Anneroth G, Gustafsson H, Tavelin B. Malignant salivary gland tumors in Sweden 1960-1989- an epidemiological study. Oral oncology. 1997;33(3):169-76.

7. Frade Gonzalez C, Lozano Ramirez A, Garcia Caballero T, Labella Caballero T. Epidemiological study of salivary gland tumors. Revue de laryngologie - otologie- rhinologie. 1999;120(5):331-6.

8. Aliyu D, Iseh KR, Sahabi SM, Amutta SB, Abdullahi M, Inch MI. Pattern of Salivary Gland Tumour in Sokota, North-Western Nigeria. International Journal of Clinical Medicine. 2016;7(5):6.

9. Bashir S, Mustafa F, Malla HA, Khan AH, Rasool M, Sharma S. Histopathological

Spectrum of Salivary Gland Tumors: A 10 Year Experience. Scholars Journal of Applied Medical Sciences (SIAMS).2013;1(6):1070-4.

10. Jaafari-Ashkavandi Z, Ashraf MJ, Moshaverinia M. Salivary gland tumors: a clinicopathologic study of 366 cases in southern Iran. Asian Pacific journal of cancer prevention (APJCP). 2013;14(1):27-30.

11. Shah JP, Patel SG, Singh B. Salivary Gland. In: Shah J, editor. Jatin Shah's Head and Neck Surgery and Oncology. Fourth ed: Elsevier; 2012. p. 542-43.

12. Spiro RH. Salivary neoplasms: Overview of a 35 year experience with 2,807 patients. Head \& Neck Surgery and Oncology. Fourth ed: Elsevier; 2012. p. 542-43.

13. Shishegar M, Ashraf MJ, Azarpira N, Khademi B, Hashemi B, Ashrafi A. Salivary Gland Tumors in Maxillofacial Region: A Retrospective Study of 130 Cases in a Southern Iranian Population. Pathology Res Int. 2011;2011:934350. doi:10.4061/2011/934350.

14. Jones AS, Hamilton JW, Rowley H, Husband D, Helliwell TR. Adenoid cystic carcinoma of the head and neck. Clinical otolaryngology and allied sciences. 1997;22(5):434-43.

15. To VSH, Chan JYW, Tsang RKY, Wei WI. Review of Salivary Gland Neoplasms. ISRN Otolaryngology. 2012;2012:6.

16. Vargas PA, Gerhard R, Araujo Filho VJF, Castro IVd. Salivary gland tumors in a Brazilian population: a retrospective study of 124 cases. Revisit do Hospital das Clinicicas. 2002;57:271-6.

17. Rajdeo RN, Shrivastava AC, Bajaj J, Shrikhande AV, Rajdeo RN. Clinicopathological study of salivary gland tumors: An observation in tertiary hospital of central India. 2017.2017;3(7):6.

18. Elumelu TN, Folasire AM, Ntekim AI, Oboh O. Salivary gland tumors in Nigerian patients - A 
10 year review. Journal of Cancer Biology and Research. 2014;2(3):1054.

19. Szanto PA, Luna MA, Tortoledo ME, White RA. Histologic grading of adenoid cystic carcinoma of the salivary glands. Cancer. 1984;54(6):1062-9.

20. Brandwein MS, Ferlito A, Bradley PJ, Hille JJ, Rinaldo A. Diagnosis and classification of salivary neoplasms: pathologic challenges and relevance to clinical outcomes. Acta otolaryngologica. 2002;122(7);758-64.

21. Salivary Glands. In: Barnes L, Eveson JW, Reichart P, Sidransky D, editors. Pathology and Genetics Head and Neck Tumours. Lyon, France: IARC; 2005. p.209-81.

Citation: Sahi R, Karmacharya D, Gautam DK, Karki AB, Shrestha A. Pattern of Major Salivary Gland Malignancies in B.P Koirala Memorial Cancer Hospital. JCMS Nepal. 2019; 15(3):202-5. 